\title{
MENINGKATKAN RASA NASIONALISME SISWA MELALUI GAME BASE LEARNING
}

\author{
Anugerah Bagus Wijaya ${ }^{1}$, Suliswaningsih ${ }^{2}$, Argiyan Dwi Pritama ${ }^{3}$ \\ 1,2 Teknik Informatika, Ilmu Komputer, Universitas Amikom Purwokerto \\ ${ }^{3}$ Sistem Informasi, Ilmu Komputer, Universitas Amikom Purwokerto \\ 1,2,3 J1. Let. Jend. Pol. Soemarto, Purwokerto, Indonesia. \\ E-Mail : ${ }^{1}$ anugerah@ amikompurwokerto.ac.id, ${ }^{2}$ suliswani@ amikompurwokerto.ac.id, \\ 3argiyandwi@amikompurwokerto.ac.id
}

\begin{abstract}
Abstrak
Kemampuan dan kemunculan teknologi pembelajaran berbasis Game ini membawa perspektif baru pembelajaran dan instruksi kedalam sebuah Game. Hal ini merupakan peluang yang signifikan bagi para pendidik dan pelatih abad ke-21 untuk meningkatkan perangkat pendidikan mereka. Dari beberapa hasil penelitian Game, ditemukan bahwa pendekatan melalui media Game Learning secara signifikan mampu mempengaruhi peningkatan prestasi, motivasi belajar, dan tingkat kepuasan dalam gaya belajar siswa. Penelitian ini fokus dalam hal meningkatkan rasa nasionalisme siswa melalui media Game Base Learning dalam pembelajaran ditingkat sekolah menengah, dimana pemain dilatih untuk menemukan, memilih, menganalisis, memutuskan mengambil sikap sendiri nilainilai hidup yang ingin diperjuangkan. Tahapan penelitian sistem Game yang akan digunakan sebagai media untuk pembelajaran rasa nasionalisme yang terdiri dari empat tahap, yakni tahap perancangan, tahap pengumpulan data, tahap analisis dan pembahasan, serta tahap dokumentasi hasil penelitian. Adupun tahapann desain Game Base Learning dengan analisa Mapping learning and Game mechanics for serious Games analysis $(L M-G M)$ sebagai pemetaan pembelajaran di dalam Game. Dilihat dari hasil pengembangan media pembelajaran melalui Game, pembelajaran aplikasikan pada Game Play menunjukkan bahwa pendekatan yang diusulkan secara efektif memberikan pemahaman atas pembelajaran yang diberikan. Selain itu, juga ditemukan bahwa media game yang dibuat dapat membantu siswa mempelajari meteri pembelajaran.
\end{abstract}

Kata Kunci : Game Base Learning, Mapping learning and Game mechanics for serious Games analysis (LM$G M)$, Nasionalisme

\begin{abstract}
The birth of Game Based Learning take a new prespective to learing method while using a Game for learning proccess. This is a good opportunity for lecturer and theacher to increas and update their learning instrument that can be used. Some studies about game founded the approach of through the medium of games of the match learning in a significant way capable of effecting the improve achievement, the motivation to study, and the level of satisfaction in the style of of students to study. This study focused on increasing students nationalism through the game base learning in learning procces for Senior high students where players trained to make a deccision, analyze, and decide own attitude in the games. This game based learning research apply for learning nationalism lessons consists of four phases, design phase, data collection stage, the analysis and discussion stage phase, the documentation and research results phase. To stage of game design base learning with learning and analysis mapping game mechanics for serious games analysis (LM-GM) as the mapping of learning in the game. The purpose through this game is learning from the game play can be shown that the approach proposed effectively gives understanding of learning that given. In addition, also found that game is can help students studies learning the history.
\end{abstract}

Keywords : Game Base Learning, Mapping learning and Game mechanics for serious Games analysis (LM-GM), Nationalism.

Author Korespondensi (Anugerah Bagus Wijaya)

Email : anugerah@amikompurwokerto.ac.id 


\section{PENDAHULUAN}

Sebagai warga bangsa Indonesia khususnya bagi generasi muda memiliki rasa nasionalisme sangat dibutuhkan untuk menjadi bangsa yang maju, aman, adil dan sejahtera serta mampu bersaing di era modern. Bangsa Indonesia yang memiliki keanekaragaman suku, budaya, agama, dan ras sangat mempengaruhi jiwa nasionalisme generasi muda bangsa Indonesia. Permasalahan seperti kemiskinan dan pengangguran sedikit banyak menimbulkan problematika lainnya. Salah satunya yaitu permsalahan terkikisnya rasa nasionalisme generasi muda. Hal ini disebabkan karena kurangnya pemikiran mayoritas masyarakat untuk partisipasi dalam nasionalisme terhadap bangsa Indonesia [1]. Nasionalisme yang merupakan kekuatan pertahanan nasional mulai dipertanyakan. Indonesia sebagai bangsa besar yang memiliki identitas luhur, sudah sepantasnya untuk berbenah diri, hal inilah yang mendorong bangsa untuk menghadapinya dengan segala macam ikhtiar antara lain melalui kebijaksanaan politik ekonomi pintu terbuka (open door policy), meningkatkan jiwa ketahanan nasional, mengumumkan gerakan kebangkitan nasional kedua, dan lainya. Kemajuan teknologi komunikasi serta informasi menyebabkan hubungan antar manusia menjadi tanpa batas (bordeless world). Dapat dikatakan bahwa manusia modern dewasa ini hidup di dalam dunia terasing, inilah paradoks dari globalisasi yang telah menyebabkan ketidakmampuan manusia untuk memperoleh pegangan hidup.

Dilihat dari 5 indikator yang digunakan untuk mengukur sikap nasionalisme di Ma Yinuba yaitu 1) Bangga terhadap bangsa Indonesia; 2) Kepedulian pada bangsa indonesia yang fokus terhadap nilai kepeduliaan sosial; 3) Cinta pada kebudayaan nasional; 4) Kewaspadaan nasional; 5) Menghormati identitas nasional, lambang negara, bahasa, lagu dan bendera kebangasaan, masih terdapat $42 \%$ siswa Ma Yinuba masih dikategorikan memiliki nasionalisme yang rendah [2]

Dalam buku Identity and Nationalism in the Balkans yang ditulis oleh Aleksandar Pavković dan Christopher dikutip dari "Nationalism and the State" Nasionalisme didasarkan pada gagasan bahwa dikatakan sebagai suatu populasi masyarakat yang disegmentasikan ke dalam kelompok yang disebut "bangsa". Suatu bangsa ini dikatakan menempati dan memiliki tempat tinggal yang disebut dengan "tanah air", memiliki sejarah (bahkan sejarah asal muasal atau keturunan), memiliki budaya, dan sering kali satu bahasa yang umum digunakan sebagai suatu perangkat simbol bangsa tersebut. Selain memiliki atribut-atribut ini, suatu bangsa juga memiliki organisasi politik yang umum, yang berdaulat, yang dikenal sebagai Negara [3].

Nilai yang terkandung didalam nasionalisme Indonesia seperti perasaan senasib, persatuan dan kesatuan, kekeluargaan, toleransi, sopan santun, tanggung jawab dan gotong royong. Hal serupa juga nyatakan oleh Dinscore and Pho dalam jurnalnya "Game Base Learning" [4] bahwa dalam nilai pendidikan karakter berkaitan dengan pembentukan sikap nasionalisme seseorang seperti kerja keras, disiplin, tanggung jawab, toleransi, dan peduli terhadap sosial. Dari dua pendapat tersebut disimpulkan bahwa bentuk yang terkandung dalam nilai nasionalisme yaitu [9]: 1) Sikap gotong royong dan peduli sosial 2) Sikap toleransi, 3) Sikap kedisiplinan, 4) Sikap kerja keras, 5) Sikap tanggung jawab, 6) Sikap sopan santun.

Banyaknya cara yang dapat digunakan dalam membantu proses belajar mengajar untuk penyajian materi pembelajaran kepada peserta didik. Kemajuan TIK baru-baru ini telah mengarah pada penerapan lingkungan dan simulasi virtual yang realistis, di mana pemain dapat hidup dalam petualangan yang menarik sambil memperoleh, mempraktekkan, dan memverifikasi pengetahuan sesuai dengan berbagai paradigma pedagogis [5]. Game yang merupakan salah satu bentuk teknologi informasi dan komputer yang digemari oleh banyak golongan, Game juga merupakan salah satu aplikasi yang edukatif, dalam hal bisa digunakan sebagai alat dalam pembelajaran dengan konsep belajar sambil bermain. Seperti dalam penerapanya Serious Games mendapatkan lebih banyak minat penelitian sebagai alat instruksional yang memanfaatkan daya tarik permainan dan keefektifan teknologi informasi dan komunikasi (TIK) [6].

Perkembangan teknologi pembelajaran berbasis Game ini membawa perspektif baru dalam pembelajaran dan instruksi kedalam sebuah Game. Hal ini merupakan peluang yang signifikan bagi para pendidik untuk meningkatkan perangkat pendidikan mereka. Pembelajaran berbasis permainan digital adalah pendekatan pendidikan yang berpusat pada siswa yang mengadopsi bentuk 
simulasi yang menempatkan siswa dalam suatu lingkungan permainan [7]. Game yang merupakan salah satu produk teknologi informasi yang cukup digemari saat ini, Game juga merupakan bentuk aplikasi yang edukatif, yang artinya bisa dijadikan sebagai media pembelajaran dimana prosesnya bisa dilakukan dengan konsep belajar sambil bermain. Seperti dalam penerapanya Serious Games mendapatkan lebih banyak minat penelitian sebagai alat instruksional yang memanfaatkan daya tarik permainan dan keefektifan teknologi informasi dan komunikasi (TIK). Pembelajaran berbasis permainan digital adalah pendekatan pendidikan yang berpusat pada siswa yang mengadopsi bentuk simulasi yang menempatkan siswa dalam suatu lingkungan permainan. Dari hasil penelitian, ditemukan bahwa pendekatan media Game Learning secara signifikan mempengaruhi peningkatan prestasi, motivasi belajar, dan tingkat kepuasan dalam gaya belajar siswa. Game mampu menjadi media alternatif yang mempermudah dalam proses pembelejaran.

Pembelajaran berbasis permainan dan gamifikasi adalah tren yang telah diterapkan di banyak tempat termasuk pelatihan di tempat kerja, pendidikan, dan social media. Pembelajaran berbasis permainan dapat digunakan dalam berbagai cara untuk meningkatkan pustaka pemikiran, dan penelitian lintas disiplin untuk mendukung keefektifannya di kelas. Ketika dirancang dengan prinsip-prinsip pembelajaran dalam pikiran, permainan dapat meningkatkan motivasi, keterlibatan, dan pembelajaran kepada siswa [8]. Digital Game Based Learning sebuah media pendukung di lingkungan kegiatan pembelajaran dengan memanfaatkan perangkat lunak dalam bentuk game [9].

Mapping Learning And Game Mechanics Analysis (Lm-Gm) merupakan sebuah mekanika untuk menggambar peta pembelajaran dan mekanik Game dalam seuah permainan Video, sehingga dapat mengidentifikasi dan menyoroti fitur pembelajaran dan hiburan utamanya, dan keterkaitannya. Metode ini juga dapat berguna untuk mengevaluasi keefektifan permainan yang diberikan dan lebih memahami bagaimana menerapkannya dalam pengaturan pendidikan.
LM-GM menggambarkan dukungan kerangka kerja dalam menentukan bagaimana Gameplay dan pedagogi terjalin dalam suatu sistem Game. Model LM-GM menghubungkan elemen strategi pembelajaran dengan sekema permainan, berikut sekema dari pemodelan LM-GM [10].

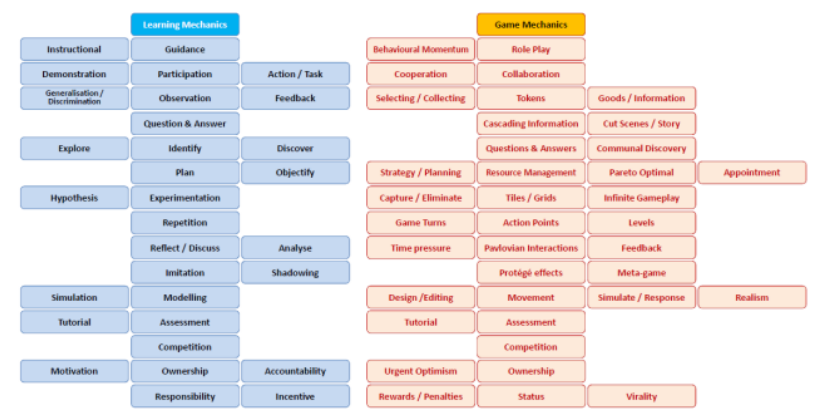

Gambar 1. Mapping Learning And Game Mechanics Analysis LM-GM

Dari hasil penelitian, ditemukan bahwa pendekatan media Game Learning secara signifikan mempengaruhi peningkatan prestasi, motivasi belajar, dan tingkat kepuasan dalam gaya belajar siswa [11]. Game mampu menjadi media alternatif yang mempermudah dalam proses pembelejaran [12].

Sebuah game dapat di definisikan sebagai suatu permainan atau aktivitas yang pada dasarnya dilakukan untuk tujuan bersenang-senang yang dijadikan sebagai hiburan dilihat dari aspek kehidupan dan imajinasi, yang membatasi perilaku-perilaku pemain dalam sebuah peraturan yang ada pada permainan game. Game adalah memiliki hubungan erat dengan pembelajaran karena mereka membuat game sesuai dengan keadaan dan kondisi nyatanya [13].

Menurut Katrin Becker dalam bukunya yang berjudul "Choosing and Using Digital Games in the Classroom”, game adalah bentuk media yang semakin banyak digunakan sebagai sarana komunikasi dan ekspresi. Akibatnya, game kini menjadi bagian dari literasi media modern yang yang berarti bahwa game juga harus menjadi bagian dari komponen dari pelatihan guru pada proyes pembelajarannya atau pelayanannya kepada siswa di kelas. Mengingat bahwa banyak program pembelajaran guru yang sudah banyak 
pula, tetapi beberapa perlakuan terhadap metode media permainan seperti ini salah satu aspek yang penting dalam menambahkan model permainan atau game ke dalam daftar metode pembelajaran untuk pendidikan. [14]

Penelitian fokus dalam cara meningkatkan rasa nasionalisme siswa melalui media Game Base Learning dalam Pendidikan sejarah ditingkat sekolah menengah dengan pendekatan pemain dilatih untuk menganalisis, memilih, menemukan dan memutuskan mengambil sikap sendiri nilainilai hidup yang ingin diperjuangkan.

\section{METODOLOGI}

Berikut ini tahapan-tahapan penelitian yang dilakukan yaitu :

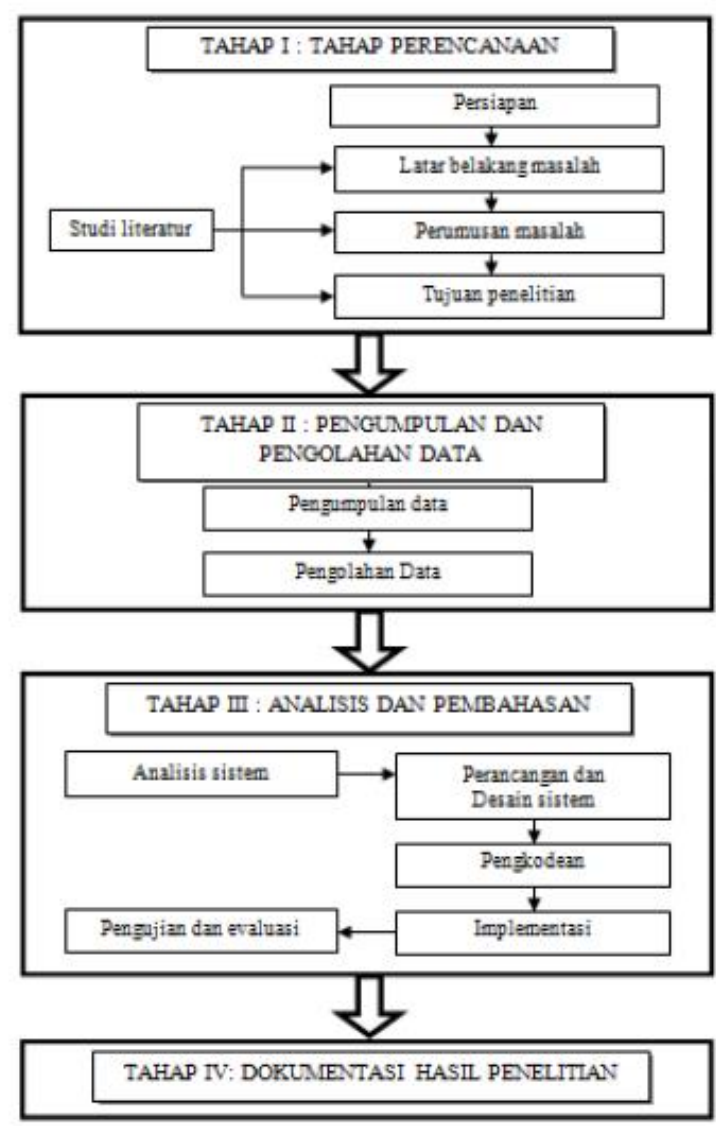

Gambar 2. Alur Penelitian

Subjek penelitian dalam hal ini adalah Game Base Learning sebagai alat untuk menanamkan rasa nasionalisme melalui Game.
Adapun sistem Game yang nantinya digunakan sebagai alat untuk pembelajaran rasa nasionalisme yang terdiri dari beberapa tahap, diantaranya perancangan, pengumpulan data, analisis, dan dokumentasi. Permainan video pembelajaran dibuat dengan beberapa tahap seperti dibawah ini :

\section{A. Tahap Pertama}

Tahap pertama yang dilakukan adalah tahap perencanaan, pada tahap ini dilakukan persiapan, perumusan masalah dan studi literature.

\section{B. Tahap Kedua}

Tahap kedua yaitu tahap pengumpulan data melalui observasi, wawancara dengan guru dari SMA MA YINUBA bapak Fergiana dicky, studi kepustakaan dan dokumentasi serta melakukan pengolahan data yang telah didapatkan. Pengumpulan data digunakan dalam memperoleh data-data yang dibutuhkan.

\section{Tahap Ketiga}

Yaitu tahap analisis dan pembahasan Pada tahap analisa sistem dilakukan oleh anggota, yang kemudian perancangan dan desain system menggunakan metode Mapping learning and Game mechanics for serious Games analysis (LM$G M)$. Diteruskan dengan pengkodean, implementasi serta pengujian dan evaluasi terhadap sistem yang diterapkan. Permainan Video pembelajaran yang sudah siap akan diperkenalkan di lingkungan sekolah MA YINUBA Purbalingga dengan mengadakan Pengujian selama 2 hari. Tahap evaluasi pengujian di lakukan dengan survei untuk mencari tahu tanggapan responden mengenai permainan video pembelajaran yang dibuat apakah mampu memberikan pengalaman bermain dan belajar yang sesui dengan nilai nasionalisme.

\section{Tahap Keempat}

Tahap keempat yaitu tahap pendokumentasian hasil dari penelitian. 


\section{HASIL DAN PEMBAHASAN}

\section{A. Analysis}

Menentukan capaian dan kebutuhan konten permainan, berdasarkan kebutuhan dan karakteristik siswa. Permainan video pembelajaran Dongeng Desa digunakan untuk menanamkan nilai nasionalisme pada pemain terutama ditingkat sekolah menengah atas SMA MA YINUBA dengan memberikan pendidikan nilai, dimana pemain dilatih untuk menganalisis, memilih, menemukan dan memutuskan mengambil sikap sendiri nilai-nilai hidup yang ingin diperjuangkan. Game play utama permainan video pembelajaran Dongeng Desa menekankan pada tindakan kegiatan bersosial seperti sikap bertoleransi, kedisiplinan, tanggungjawab, kerja keras, sopan santun dan gotong royong.

\section{B. Design}

Menetukan elemen pembelajaran yang akan terapkan pada permaianan berdasarkan dari hasil analisis sebelumnya. Pembelajaran yang akan dimuat dalam game dapat di lihat pada tabel 1.

Tabel 1. Klasifikasi pembelajaran dengan HOT's

\begin{tabular}{|c|c|c|}
\hline $\begin{array}{c}\text { Mekanika } \\
\text { Permainan }\end{array}$ & $\begin{array}{c}\text { Thingking } \\
\text { Skill }\end{array}$ & $\begin{array}{c}\text { Mekanika } \\
\text { Pembelajaran }\end{array}$ \\
\hline Dialog & Creating & Menemukan \\
\hline Memberi misi & Evaluating & Menganalisis \\
\hline $\begin{array}{c}\text { Mengambil } \\
\text { misi }\end{array}$ & Analysing & Memilih \\
\hline $\begin{array}{c}\text { Menjalankan } \\
\text { misi }\end{array}$ & Appling & Sikap \\
\hline $\begin{array}{c}\text { Menyelesaikan } \\
\text { misi }\end{array}$ & Understanding & Nilai hidup \\
\hline $\begin{array}{c}\text { Hadiah, } \\
\text { Penghargaan }\end{array}$ & Retention & Nilai hidup \\
\hline
\end{tabular}

Selanjutnya membuat dan merancang desain permainan yang akan dibuat. Perancangan desan permainan terdiri dari cerita permainan, alur permainan, karakter, mekanika permainan, musuh, dan potongan cerita.

Pemetaan pembelajan didalam permainan di tentukan menggunakan LM-GM. Untuk menentukan dan melihat fitur yang sesui dengan konsep permainan yang nantinya akan di gunakan dengan cara menentukan komponen permainan komponen pembelajaran dengan penerapan desain permainan. Berikut pemetaan penerapan konsep pembelajaran dan permainan dari desain permainan yang telah di buat dapat dilihat pada tabel 2.

Tabel 2. Pemetaan LM-GM

\begin{tabular}{|c|c|c|c|}
\hline $\begin{array}{c}\text { Sistem } \\
\text { Permainan }\end{array}$ & $\begin{array}{c}\text { Sistem } \\
\text { Pembelajaran }\end{array}$ & Implementasi & Keterangan \\
\hline & & Mulai & $\begin{array}{l}\text { Pemain Bertemu } \\
\text { NPC }\end{array}$ \\
\hline Story, Role Play & Instruction & Dialog & $\begin{array}{l}\text { Percakapan tentang } \\
\text { materi, Sikap Sopan } \\
\text { santun }\end{array}$ \\
\hline $\begin{array}{l}\text { Strategy, } \\
\text { Resource } \\
\text { Management, } \\
\text { Information }\end{array}$ & $\begin{array}{l}\text { Plan, } \\
\text { Explorasi }\end{array}$ & Memberi misi & $\begin{array}{l}\text { Sebuah tugas } \\
\text { disertai informasi } \\
\text { ketentuan dan } \\
\text { kriteria tugas } \\
\text { pencarian/penakluk } \\
\text { an, Sikap toleransi }\end{array}$ \\
\hline $\begin{array}{l}\text { Cooperation, } \\
\text { Selecting, } \\
\text { Competition, } \\
\text { Cascading } \\
\text { Information }\end{array}$ & $\begin{array}{l}\text { Task, } \\
\text { Observation, } \\
\text { Assesment }\end{array}$ & Mengambil Misi & $\begin{array}{l}\text { Pemain mngambil } \\
\text { misi yang diberikan } \\
\text { oleh NPC, Sikap } \\
\text { Gotong royong, } \\
\text { Sikap } \\
\text { Tanggungjawab }\end{array}$ \\
\hline $\begin{array}{l}\text { Resource } \\
\text { Management, } \\
\text { Cooperation, } \\
\text { Collecting, } \\
\text { Simulate }\end{array}$ & $\begin{array}{l}\text { Observation, } \\
\text { Simulation, } \\
\text { Partisipation, } \\
\text { Experimentati } \\
\text { on }\end{array}$ & $\begin{array}{l}\text { Menjalankan } \\
\text { misi }\end{array}$ & $\begin{array}{l}\text { Pemain } \\
\text { menjalankan misi } \\
\text { seperti pencarian / } \\
\text { penaklukan, Sikap } \\
\text { Kerjakeras, Sikap } \\
\text { Kedisiplinan } \\
\end{array}$ \\
\hline Feedback & Feedback & $\begin{array}{l}\text { Menyelesaikan } \\
\text { misi }\end{array}$ & $\begin{array}{l}\text { Pemain } \\
\text { menyelesaikain } \\
\text { misi } \\
\text { pencarian/penakluk } \\
\text { an, Sikap } \\
\text { Kedisiplinan }\end{array}$ \\
\hline $\begin{array}{l}\text { Competition, } \\
\text { Rewards }\end{array}$ & $\begin{array}{l}\text { Motivation, } \\
\text { Incentive }\end{array}$ & $\begin{array}{l}\text { Mendapat } \\
\text { Hadiah }\end{array}$ & $\begin{array}{l}\text { Pemain } \\
\text { mendapatkan } \\
\text { hadiah, Sikap } \\
\text { Gotong royong }\end{array}$ \\
\hline
\end{tabular}

\section{Development}

Tahap pertama membuat lingkungan permainan, dengan mengatur dan menentukan lingkungan yang akan dibuat berdasarkan desain permainan yang telah dibuat pada tahap sebelumnya. 


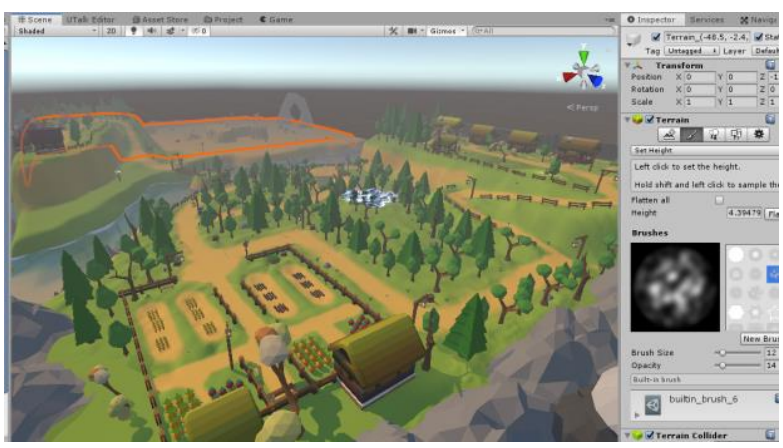

Gambar 1. Lingkungan Permainan

Membubat Dioalog System yang nantinya akan digunakan sebagai bahat percakapan antara karakter pemain dan NPC. Dialog sytem ini terdiri dari pembuatan UI dialog dilihat pada gambar 2 berisi gambar karakter, nama karakter dan text box yang memuat informasi percakapan. Di dalam texbo dialog terdapat tombol pilihan sebagai aksi pemain agar memilih pertanyaan atau pun jawaban yang ingin di pilih.

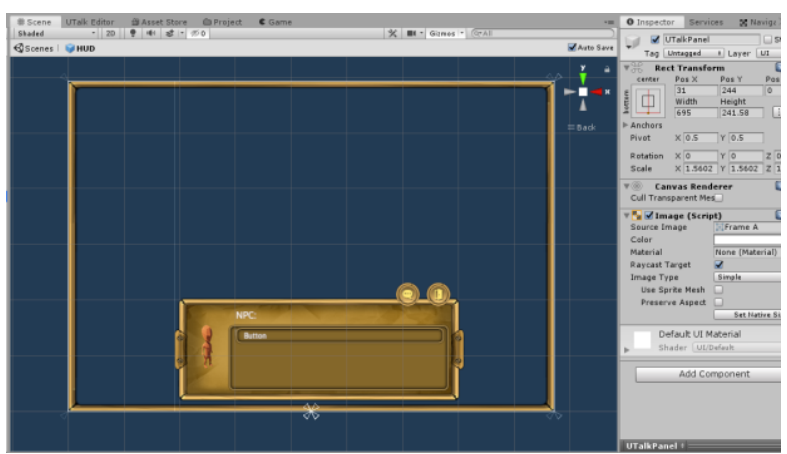

Gambar 2. UI Dialog System

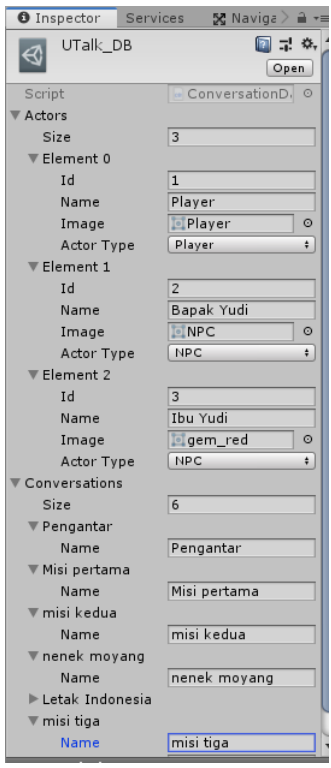

Gambar 3. Menentukan tokoh dan Tema percakapan

Pada gambar 3 karakter NPC di buat di tentukan juga nama dan gambar karakternya, nantinya nama dan gambar karakter ini akan di munculkan di UI dialog seperti gambar 2 (cek penomorane aku sesui nomor neng dile iki). Tema dialog terdapat 2 jenis yakni dialog materi dan misi.

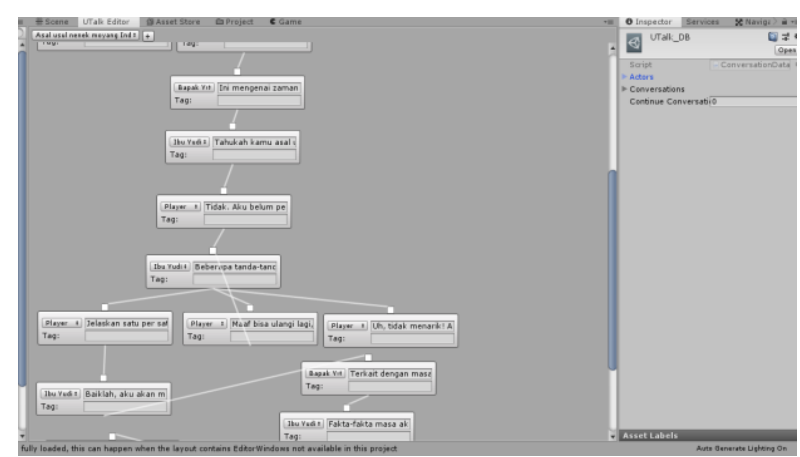

Gambar 4. Naskah Dialog

Proses pembuatan naskah dialog dilihat pada gambar 4. Memnentukan dialog antara pemain dengan npc, percabangan dalam dialog dibuat agar pemain memilih nilai dalam percakapan yang akan pemain tentukan. (olah mening kayane bahasane orapas) dialog akan di munculkan pada tex box UI dialog gambar 3 .

Pada tahap selanjutnya prmnuatan event dan mekanika permainan gambar 5 desain mekanika permainan seperti kontrol karakter, aksi, misi, sistem kesehatan pemain dilihat dai desain UI.

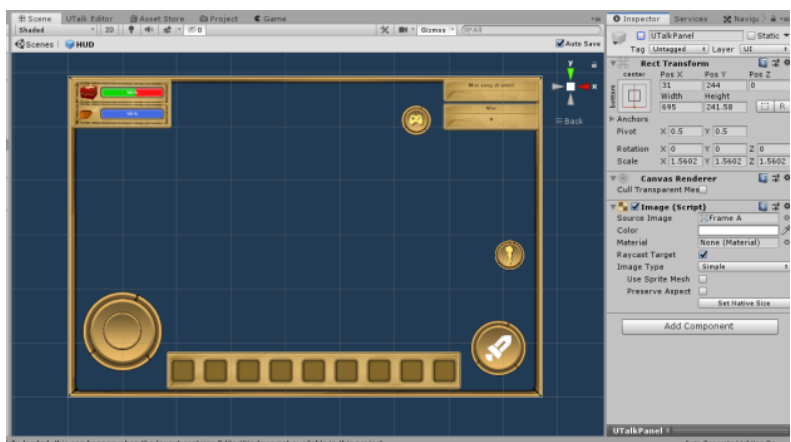

Gambar 5. UI Mekanika Permainan

Berikut hasil dari pengembangan media pembelajaran permainan video yang di buat dengan ML-GM. 


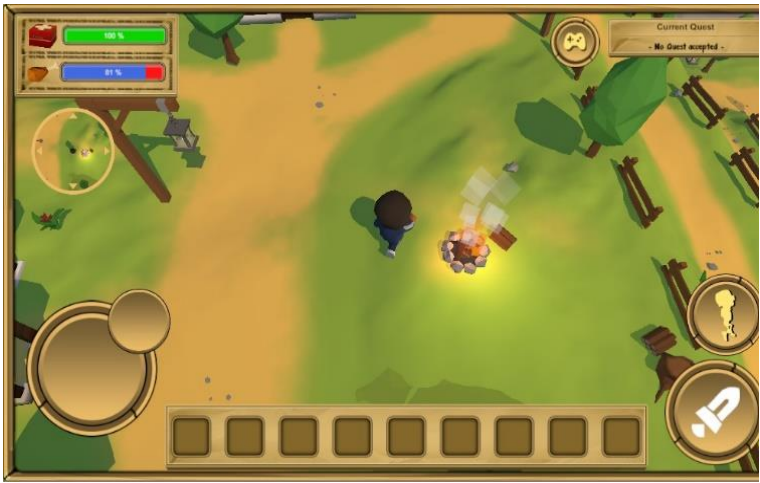

Gambar 6. Tampilan Mulai Permainan

Pada tampilan ini terdapat beberapa fitur seperti pengendali karakter, pengendali aksi, dan juga informasi karakter seperti indikator kesehatan dan stamina, informasi misi dan peta kecil.

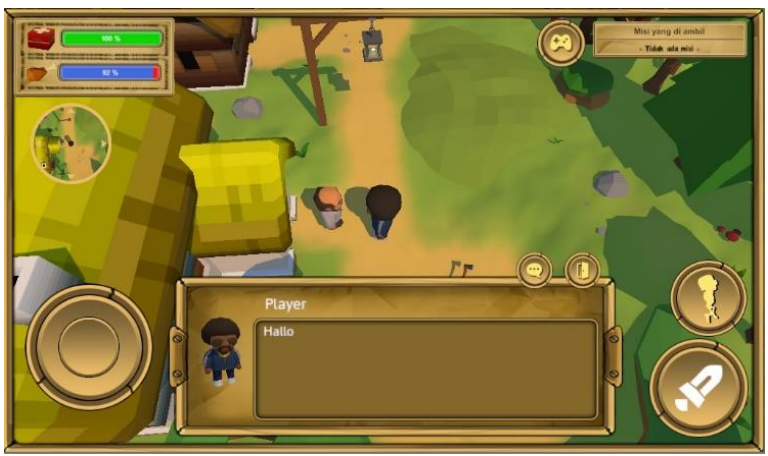

Gambar 7. Tampilan Dialog

Dialog digunakan sebagai tempat percakapan antara pemain dan Non Player Character (NPC). Percakapan dalam dialog membahas topik yang disesuikan dengan poin pokok bahasan materi tiap bab pada pelajaran sejarah kelas X. Bentuk percakapan berupa diskusi dan juga dalam bentuk informasi materi. Pengambilan nilai bertoleransi dan sopan santun di terap kan melalui dialog.

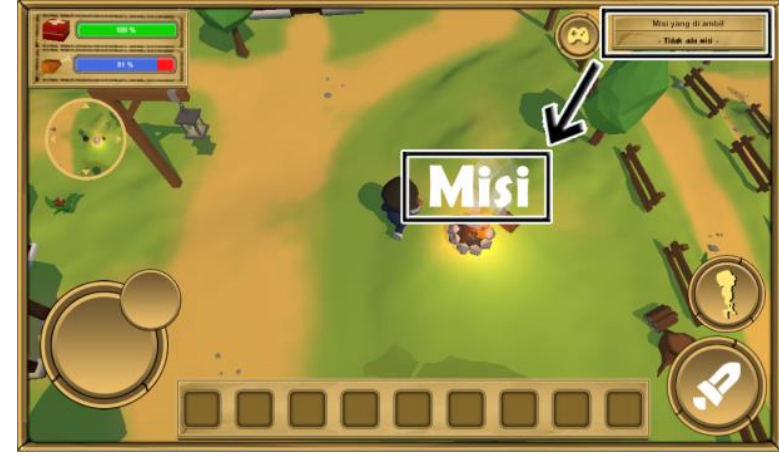

Gambar 8. Tampilan Misi

Misi ditekankan sebagai nilai gotong royong kedisiplinan, tanggung jawab, dan kerja keras pada nilai nasionalisme. Melalui misi pemain akan membantu NPC dalam keperluan sebagai tugas yang harus diselesaikan.

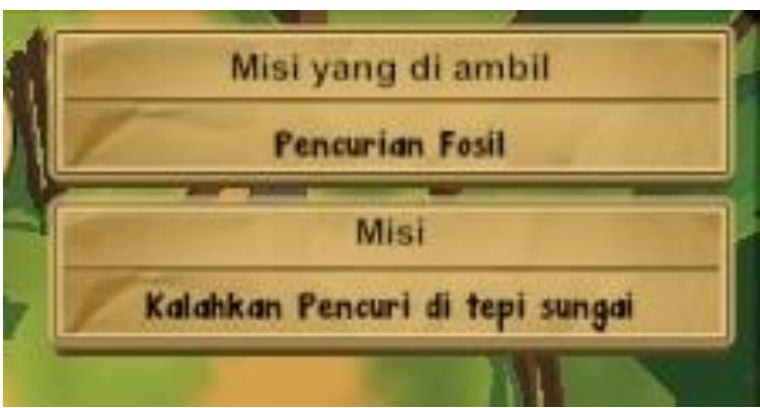

Gambar 9. Contoh Misi

Dengan menyelesaikan misi pemain akan bekerjakeras untuk menyelesaikanya bisa dalam bentuk mencari benda maupun mengalahkah musuh. Ketika pemain mengambil misi pemain tidak dapat mengambil misi lain hal ini sebagai nilai kedisiplinan dan tanggung jawab.

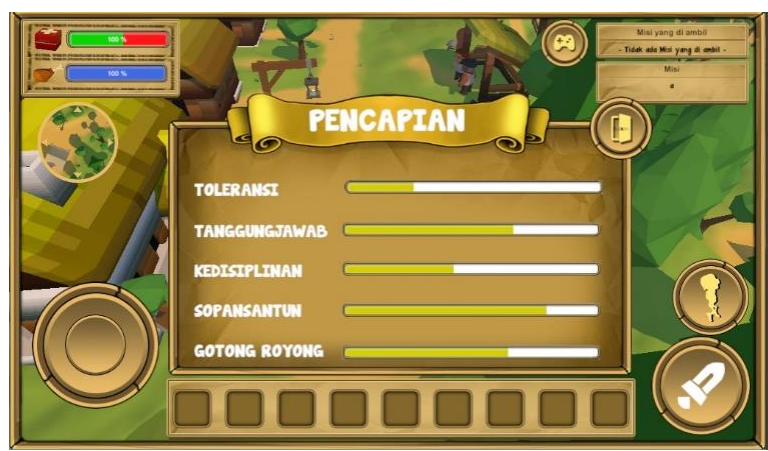

Gambar 10. Tampilan Capaian 
Tampilan capaian menampilkan informasi nilai dari sikap bertoleransi, kedisiplinan, tanggungjawab, kerjakeras, sopan santung dan gotong royong yang telah dicapai.

\section{Quality Assurance}

Pengujian menggunakan metode Balackbox untuk menguji fungsionalitas pada game sehingga dapat dilakukan perbaikan sebelum pengujian implementasi pada pengguna.

Pengujian konten pembelajaran sejarah dilakukan dengan ahli materi yakni guru matapelajaran yang juga menjadi walikelas siswa kelas $\mathrm{X}$ dengan tujuan materi ataupun pembelajaran sesuai dengan tujuan atau capaian pembelajaran.

\section{E. Implementation} $\mathrm{X}$.

Survei di lakukan pada siswa Ma Yinuba kelas

Tabel 3. Penghitungan Sekala Linkert

\begin{tabular}{|l|c|c|c|c|c|}
\hline \multicolumn{1}{|c|}{ Pernyataan } & SS & S & CS & TS & STS \\
\hline Pernyataan 1 & 15 & 10 & 2 & & \\
\hline Pernyataan 2 & 10 & 11 & 6 & & \\
\hline Pernyataan 3 & 12 & 12 & 3 & & \\
\hline Pernyataan 4 & 9 & 11 & 5 & 2 & \\
\hline Pernyataan 5 & 15 & 8 & 4 & & \\
\hline Pernyataan 6 & 13 & 9 & 4 & 1 & \\
\hline Pernyataan 7 & 8 & 17 & 2 & & \\
\hline Pernyataan 8 & 13 & 8 & 6 & & \\
\hline JUMLAH & 95 & 86 & 32 & 3 & \\
\hline $\begin{array}{l}\text { JUMLAH } \\
\text { SKOR }\end{array}$ & 475 & 344 & 96 & 6 & \\
\hline SKOR & \multicolumn{7}{|c|}{921} \\
\hline MAX SKOR & \multicolumn{7}{|c|}{$85 \%$} \\
\hline $\begin{array}{l}\text { PRESENTASE } \\
\text { (\%) }\end{array}$ & \multicolumn{7}{|c|}{} \\
\hline
\end{tabular}

Dari tabel 3 hasil Survei yang telah dilakukan dengan 27 responden siswa Madrasah Yinuba, dengan 8 pertanyaan evaluasi mengani game yang telah di bangun di dapati nilai menggunakan sekala linkert, dilihat dari data nilai Obserfasi sebesar 921 dan nilai yang diharapkan adalah
1080, maka didapati hasil nilai indeks presentasi sebesar $85 \%$ maka dapat disimpulkan bahwa setuju permainan video pembelajaran yang dibuat memberikan pengalaman bermain dan belajar yang sesui dengan nilai nasionalisme seperti sikap bertoleransi, kedisiplinan, tanggungjawab, sopan santun, kerja keras dan gotong royong.

\section{SIMPULAN DAN SARAN}

Media Pembelajaran berupa permainan video menggunakan metode DGBL-ID telah di bangun. Dilihat dari hasil pengujian pengembangan media pembelajaran yang telah di bangun, pembelajaran yang di aplikasikan pada Game Play menunjukkan bahwa pendekatan yang yang diusulkan secara efektif memberikan pemahaman atas pembelajaran yang diberikan. Selain itu, juga ditemukan bahwa media game yang dibuat dapat membantu siswa mempelajari meteri pembelajaran.

Dilihat dari hasi pengujian dan observasi lapangan, untuk tahap pengembangan dan penelitian selanjutnya dapat di ujikan kepada responden yang lebih luas lagi bisa kepada masyarakat umum dan untuk pengembangan video permainan dapat di implementasikan pada matapelajaran lainya dan tingkat pendidikan lainya.

\section{REFERENSI}

[1] A. Amrah, "Mengulik Pengembangan Nasionalisme Generasi Muda Di Era Globalisasi," Publ. Pendidik., vol. 6, no. 2, 2017.

[2] F. Fitriani, T. Rahamma, and M. Nadjib, "Pemanfaatan Teknologi Digital Dalam Pembelajaran IPS Guna Menumbuhkan Jiwa Nasionalisme Dan Patriotisme Digital Technology Utilization In The Learning Of Social Sciences In Encouraging Nationalism And Patriotism Of Learners Of SMPN 12 Kendari Pendahuluan," vol. 6, no. 1, 2017.

[3] J. Breuilly, Nationalism and the State. Chicago: St. Martin's Press: New York, 1982. 
[4] A. Pho and A. Dinscore, "Game-based Learning," Assoc. Coll. Res. Libr. Am. Libr. Assoc., 2015.

[5] L. Sa'diyah, "Peranan Guru Sejarah dan Pendidikan Karakter dalam Pembentukan Sikap Nasionalisme Siswa," 2012.

[6] Z. Rohmah, "Pengaruh Perspektif Modernis Terhadap Perilaku Nasionalisme Pada Siswa SMA Negeri 1 Bantan Pengaruh Perspektif Modernis Terhadap Perilaku," pp. 1-14.

[7] F. Bellotti, R. Berta, A. De Gloria, and L. Primavera, "Player experience evaluation: An approach based on the personal construct theory," Lect. Notes Comput. Sci. (including Subser. Lect. Notes Artif. Intell. Lect. Notes Bioinformatics), vol. 5709 LNCS, pp. 120 131, 2009.

[8] P.-H. Hung, G.-J. Hwang, Y.-H. Lee, and I.$\mathrm{H}$. Su, "A cognitive component analysis approach for developing Game-based spatial learning tools," Comput. Educ., vol. 59, no. 2, pp. 762-773, 2012.

[9] Brom C., Sisler V., Slavik R. "Implementing digital game-based learning in school: Augmented learning environtment of "Europe 2045". Multimedia System. Vol. 16
(1): 23-41, 2009.

[10] S. Arnab, T. Lim, M. C. B, and et al, "Mapping learning and Game mechanics for serious Games analysis. British Journal of Educational Technology," vol. 46 (2), pp. 391-411, 2015.

[11] G.-J. Hwang, L.-Y. Chiu, and C.-H. Chen, "A contextual Game-based learning approach to improving students' inquirybased learning performance in social studies courses," Comput. Educ., vol. 81, pp. 13-25, 2015.

[12] S. Rochmat and D. Trisnawati, "Penanaman Nilai-Nilai Nasionalisme dalam Pembelajaran Sejarah di SMA Negeri 2 Wates, Kulon Progo," vol. 13, no. 1, 2017.

[13] Shaffer DW., Squire KD., Halverson R., \& Gee JP. Video games and the future of learning. Phi Delta Kappan: WisconsinMadison University, 2004.

[14] Becker, Katrin. "Choosing and Using Digital Games in the Classroom". Springer International Publishing Switzerland. 2017. 